\title{
Peran Guru Dalam Mengatasi Kesulitan Belajar Siswa Pada Mata Pelajaran Matematika di MI Ummul Qura
}

\author{
${ }^{1}$ Mardiah ${ }^{2}$ Ahmad Rifa'I \\ Instruktur Tahfiz Sekolah Tinggi Ilmu Al-Quran. Email : \\ mardiahnor08@gmail.com dan ahmadrifai210788@gmail.com
}

\begin{abstract}
Abstrak
Penelitian ini dilatar belakangi adanya siswa yang mengalami kesulitan pada pelajaran matematika dan nilai yang tidak mencapai standar KKM. Penelitian ini mengemukakan tentang peran guru dalam mengatasi kesulitan belajar siswa pada mata pelajaran matematika kelas 5 di MI Ummul Qura. Penelitian ini meneliti "Bagaimana peran guru dalam mengatasi kesulitan belajar siswa pada mata pelajaran matematika kelas 5 di MI Ummul Qura dan faktor-faktor apa saja yang mempengaruhi kesulitan siswa pada mata pelajaran matematika kelas 5 di MI Ummul Qura."

Penelitian ini merupakan penelitian deskriptif kualitatif. Pengumpulan data dalam penelitian ini adalah metode pengamatan atau observasi, wawancara atau interview, dan dokumentasi. Proses analisis data yakni dengan menelaah seluruh data dari hasil observasi, hasil wawancara, dan dokumenter yang berhubungan dengan pembelajaran matematika, pengecekan keabsahan temuan dilakukan dengan cara keikutsertaan peneliti.

Hasil temuan dalam penelitian ini menunjukkan bahwa peran guru dalam mengatasi kesulitan belajar siswa pada mata pelajaran matematika di MI Ummul Qura adalah sudah sesuai dengan teori-teori yang telah dipaparkan. Guru menjalankan dengan baik perannya sebagai demonstrator, pengelola kelas, motivator, mediator, fasilitator, dan evaluator. Sedangkan faktor-faktor yang mempengaruhi kesulitan siswa pada mata pelajaran matematika di MI Ummul Qura terdiri dari faktor internal yang meliputi, minat, kecerdasan atau intelegensi siswa, kemauan belajar, dan kondisi tubuh. Adapun faktor eksternal meliputi, Lingkungan dan teman sebaya, media massa atau teknologi, suasana pengajaran, dan lingkungan keluarga.
\end{abstract}

Kata kunci: Kesulitan Belajar; Matematika; MI Ummul Qura; Peran Guru; 


\section{A. Pendahuluan}

Kegiatan belajar mengajar merupakan kegiatan yang sangat penting dalam proses pendidikan. Belajar merupakan interaksi atau hubungan yang terjalin antara pendidik dengan peserta didik yang dilakukan secara sadar dan terencana baik di dalam maupun di luar ruangan dengan tujuan untuk meningkatkan kemampuan peserta didik. Belajar juga berarti interaksi yang dilakukan secara sadar dan terencana antara guru dengan siswa yang dilaksanakan baik di dalam kelas maupun diluar kelas dalam rangka untuk meningkatkan kemampuan siswa. ${ }^{1}$

Mengajar adalah suatu aktivitas mengorganisasi atau mengatur kegiatan belajar. Mengajar sebagai upaya menciptakan situasi dan kondisi yang kondusif untuk berlangsungnya kegiatan belajar bagi para siswa. Kondisi itu diciptakan sedemikian rupa sehingga membantu perkembangan anak secara optimal baik jasmani maupun rohani, baik fisik maupun mental. ${ }^{2}$

Kegiatan belajar mengajar adalah suatu keadaan yang dengan sengaja diciptakan oleh guru untuk memberikan pengajaran kepada peserta didik. Dalam kegiatan ini gurulah yang mengajar dan peserta didik yang belajar. Dari perpaduan kedua unsur manusiawi ini maka

${ }^{1}$ Muhammad Afandi, Evi Chamalah, dan Oktarina Puspita Wardani, Model Dan Metode Pembelajaran Di Sekolah (Semarang:Unissula Press, 2013), h. 3.

${ }^{2}$ Sardiman, Interaksi\&Motivasi Belajar Mengajar (Jakarta:Rajawali Pers, 2009), h. 48. 
akan menghasilkan interaksi edukatif dengan memanfaatkan bahan sebagai perantaranya. Dalam kegiatan ini, untuk mencapai tujuan pengajaran yang telah ditetapkan sebelum pengajaran dilaksanakan maka semua komponen pengajaran harus diperankan secara optimal. $^{3}$

Salah satu orang yang terlibat dalam kegiatan belajar mengajar diantaranya ialah seorang guru. Guru merupakan salah satu faktor utama yang menentukan mutu pendidikan. Gurulah yang berada di garda terdepan dalam menciptakan kualitas sumber daya manusia. Melalui proses belajar mengajar guru berhadapan langsung dengan para peserta didik dikelas. Di tangan gurulah akan dihasilkan peserta didik yang berkualitas, baik secara akademis, skill (keahlian), kematangan emosional, dan moral serta spiritual. Dengan demikian akan dihasilkan generasi muda yang siap hidup dalam menghadapi tantangan zamannya. Oleh karena itu, diperlukan sosok guru yang mempunyai kualifikasi, kompetensi, dan dedikasi yang tinggi dalam menjalankan tugas profesionalnya. ${ }^{4}$

Seorang guru bukan hanya menjadi seorang tenaga pengajar, bahkan lebih dari itu guru menjadi sumber perbaikan, figur yang patut menjadi contoh, tauladan dan memberikan bimbingan kepada

${ }^{3}$ Muhammad Afandi, Evi Chamalah, dan Oktarina Puspita Wardani, Model Dan Metode ..., h. 3.

${ }^{4}$ Kunandar, Guru Profesional: Implementasi Kurikulum Tingkat Satuan Pendidikan (KTSP) dan Sukses dalam Sertifikasi Guru (Jakarta: PT RajaGrafindo Persada, 2007), h. 40. 
anak didiknya. Guru memiliki tugas yang sangat penting, gurulah yang mengembangkan ilmu pengetahuan dan memperbaiki masyarakat. ${ }^{5}$ Masyarakat menganggap kedudukan guru sebagaiorang yang lebih terhormat di lingkungan karena masyarakat mengharapkan untuk memperoleh ilmu pengetahuan dari seorang guru. $^{6}$

Bahkan dalam agama Islam, guru sebagai orang yang berilmu memiliki kedudukan yang tinggi. Hal ini sebagaimana tercantum dalam Firman Allah SWT. Q.S. Al-Mujadalah/58:11 yang berbunyi:

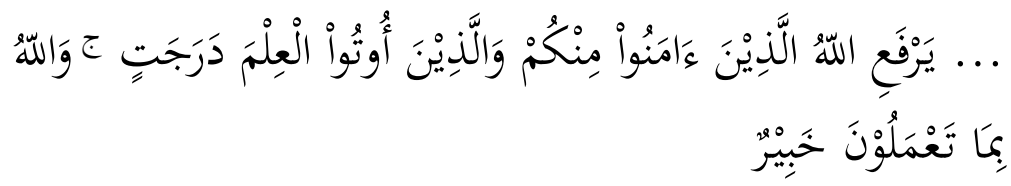

"Artinya:...Allah akan mengangkat (derajat) orang-orang yang beriman di antaramu danorang-orang yang diberi ilmu pengetahuan beberapa derajat. Dan Allah Maha Teliti apa yang kamu kerjakan.(Q.S. Al-Mujadalah/58:11)."

Guru memiliki peranan yang sangat penting dalam kegiatan belajar mengajar. Menurut Drs. Moch. Uzer. Usman dalam bukunya Menjadi Guru Profesional menyebutkan bahwa:

"Proses belajar-mengajar dan hasil belajar siswa sebagian besar ditentukan oleh peranan dan kompetensi guru. Guru yang kompeten akan lebih mampu menciptakan lingkungan belajar yang efektif dan akan lebih mampu mengelola

${ }^{5}$ Nurfuadi, Profesionalisme Guru, Cet. 1 (Purwokerto:STAIN Press, 2012), hal, $110-111$.

${ }^{6}$ Moch. Uzer Usman, Menjadi Guru Profesional,Cet. 27 (Bandung:PT Remaja Rosdakarya, 2013), hal. 7.

${ }^{7}$ Departemen Agama RI, Al-Qur'an dan Terjemahnya (Jawa Barat: CV Penerbit Diponegoro, 2015), hal, 543. 
kelasnya sehingga hasil belajar siswa berada pada tingkat optimal". 8

Ketika proses belajar mengajar, guru akan dihadapkan pada anak didik yang anak didik yang berbeda-beda aktivitas belajarnya karena tidak selamanya aktivitas belajar setiap siswa dapat berlangsung secara wajar atau baik-baik saja. Kadangkala proses belajar berjalan dengan lancar, kadang pulatidak, ada yang cepat menangkap apa yang dipelajari dan ada juga yang merasa kesulitan. Setiap individu memang berbeda, perbedaan individual inilah yang menyebabkan perbedaan tingkah laku belajar di kalangan anak didik. Dalam pembelajaran, ada anak didik yang tidak dapat belajar sebagaimana mestinya atau yang dinamakan dengan kesulitan belajar. $^{9}$

Sehubungan dengan itu sesuai dengan perannya sebagai pembimbing, maka guru harus membantu siswa mengatasi kesulitan belajar yang dialaminya dalam proses pembelajaran karena guru adalah aktor utama, dialah yang menentukan berhasil atau tidaknya suatu proses pembelajaran. ${ }^{10}$ Oleh karena itu, jika seorang guru ingin proses pembelajaran yang ia jalankan itu berhasil dan dapat diterima dengan mudah oleh peserta didik, maka guru harus berperan aktif

${ }^{8}$ Moch. Uzer Usman, Menjadi Guru Profesional..., hal. 9.

${ }^{9}$ Abu Ahmadi dan Widodo Supriyono, Psikologi Belajar (Jakarta:Rineka Cipta, 2013), h. 77.

${ }^{10}$ Nurfuadi, Profesionalisme Guru ..., h. 129-30. 
dalam membantu serta mengatasi kesulitan belajar yang dialami siswanya.

Salah satu mata pelajaran yang diajarkan di tingkat MI adalah matematika. Matematika adalah salah satu bidang studi yang ada pada semua jenjang pendidikan, mulai dari tingkat sekolah dasar sampai perguruan tingi. Bahkan di taman kanak-kanak matematika sudah diajarkan walaupun masih secara informal. Belajar matematika merupakan salah satu syarat untuk melanjutkan pendidikan ke jenjang yang lebih tinggi. Dengan belajar matematika, kita akan belajar bernalar secara kritis, kreatif dan aktif. ${ }^{11}$

Banyak yang beranggapan bahwa matematika adalah bidang studi yang paling sulit. Meskipun demikian, matematika merupakan sarana untuk memecahkan masalah dalam kehidupan sehari-hari. Oleh sebab itu semua orang harus mempelajarinya. Seperti halnya bahasa, membaca, dan menulis, kesulitan belajar matematika harus diatasi sedini mungkin, jika tidak siswa akan menghadapi banyak kesulitan karena hampir semua bidang studi memerlukan matematika. $^{12}$

Menurut teori kognitif Piaget, usia siswa sekolah dasar (7-8 tahun hingga 12-13 tahun) termasuk pada tahap operasional konkret

\footnotetext{
${ }^{11}$ Ahmad Susanto, Teori Belajar \& Pembelajaran di Sekolah Dasar,Cet. 4 (Jakarta:Prenadamedia Group, 2016), h. 183.

${ }^{12}$ Mulyono Abdurrahman, Anak Berkesulitan Belajar: Teori, Diagnosis, Dan Remediasinya,Cet. 1 (Jakarta:Rineka Cipta, 2012), h. 202.
} 
yang mana anak pada usia ini pada umumnya mengalami kesulitan dalam memahami matematika yang bersifat asbstrak. ${ }^{13}$

Berdasarkan hasil riset Trends in International Mathematics and Science Study (TIMSS) $^{14}$ pada tahun 2015 menempatkan Indonesia di posisi 45 dari 48 pada bidang IPA dan posisi 45 dari 50 negara pada bidang matematika. Hal ini menunjukkan bahwa kemampuan siswa Indonesia dalam menyelesaikan permasalahan matematika yang menuntut kemampuan untuk meneliti, penalaran, dan berkomunikasi secara efektif, dan memecahkan dan menafsirkan masalah dalam berbagai situasi masih sangat rendah. ${ }^{15}$

Dilihat dari hasil PISA $^{16}$ beberapa tahun sebelumnya hasilnya belum memuaskan. Hasil studi terakhir PISA tahun 2015 menunjukkan Indonesia dengan skor 386 dalam bidang kompetensi matematika memang mengalami kenaikan jika dibandingkan dengan tahun 2012 dengan skor 375. Namun, jika dibandingkan dengan rata-

\footnotetext{
${ }^{13}$ Ahmad Susanto, Teori Belajar \& Pembelajaran ..., h. 184.

${ }^{14}$ TIMSS (Trends in International Mathematics and Science Study) adalah studi internasional yang mengukur kemampuan matematika dan sains. TIMSS bertujuan untuk melihat bagaimana kurikulum yang dicanangkan oleh setiap negara diimplementasikan dan capaian siswa khususnya pada bidang matematika dan sains. TIMSS diselenggarakan setiap 4 tahun sekali dan dikoordinasikan oleh IEA(the International Association for the Evaluation of Educational Achievement).

${ }^{15}$ Elsa Susanti dan Salmaini Safitri Syam, "Peran Guru dalam Meningkatkan Kemampuan Literasi Matematika Siswa Indonesia," Seminar Matematika Dan Pendidikan Matematika UNY(2017): h. 273.

${ }^{16}$ PISA (The Programme for International Student Assessment) adalah studi yang dikembangkan oleh beberapa negara maju di dunia yang tergabung dalam OECD yang berkedudukan di Paris, Prancis. Indonesia telah berpratisipasi dalam program ini mulai tahun 2000 dan pertama kali diikuti oleh 43 negara peserta. Studi PISA menghasilkan profil kemampuan siswa berusia 15 tahun dalam membaca, matematika, sains, dan problem solving, termasuk indikator "trend" yang menunjukkan perubahan kemampuan siswa dari waktu ke waktu.
} 
rata keseluruhan yaitu 490, maka tingkat pencapaiannya masih dibawah rata-rata. ${ }^{17}$ Dengan demikian, dilihat dari data penelitianpenelitian tersebut menunjukkan bahwa tingkat kemampuan dan penguasaan pelajar Indonesia dalam bidang matematika masih rendah dan dibawah rata-rata.

Berdasarkan observasi yang dilakukan peneliti di MI Ummul Qura dan hasil wawancara dengan Ustadzah Malisa, beliau mengatakan MI Ummul Qura merupakan salah satu sekolah yang bagus sistem pendidikannya. Hal ini ditunjukkan dengan jumlah siswa yang tiap tahunnya makin bertambah banyak. Proses penerimaan siswa baru pun dilakukan dengan mengadakan tes tertulis dan mengaji untuk mengetahui kemampuan siswa. Di MI Ummul Qura ini siswa-siswanya dibimbing untuk menghafal Alquran sejak dini. Selain itu, sekolah ini juga membuat buku penghubung antara orang tua dan guru serta mengirim pesan (SMS) kepada orang tua ketika siswa sudah dirumah untuk mengingatkannya bangun subuh, shalat subuh, murajaah hafalan dan sebagainya. Selain itu, sama seperti sekolah Islam terpadu (IT) lainnya, sekolah ini dalam kurikulumnya juga melaksanakan sistem

${ }^{17}$ Usman Arifin dan Ratni Purwasih, "Penerapan Pembelajaran Berbasis Alternative Solutions Worksheet Untuk Meningkatkan Kemampuan Berpikir Kreatif Matematik," Jurnal Pendidikan Matematika FKIP Universitas Muhammadiyah 6, no. 2 (2017): h. 226. 
integrasi dengan mengaitkan mata pelajaran agama dan umum dalam sistem pembelajarannya. ${ }^{18}$

Berdasarkan observasi yang dilakukan peneliti di lapangan, terdapat beberapa siswa yang mengatakan bahwa mereka mengalami kesulitan dalam pelajaran matematika dan berdasarkan wawancara dengan Ustadzah Herlina guru matematika di kelas 5, beliau mengatakan bahwa dengan standar nilai KKM 70, di sekolah tersebut khususnya kelas 5 masih ada siswa yang nilai matematikanya tidak mencapai KKM walaupun telah dilakukan remedial. ${ }^{19}$

\section{B. Metode Penelitian}

Penelitian ini merupakan penelitian deskriptif kualitatif. Pengumpulan data dalam penelitian ini adalah metode pengamatan atau observasi, wawancara atau interview, dan dokumentasi. Sumber data berupa data primer dan data sekunder, sumber data primer yang dipilih dalam penelitian ini yaitu : narasumber (informan), peristiwa atau aktivitas, tempat atau lokasi. Sumber data sekunder yang menjadi rujukan peneliti dalam hal ini adalah semua dokumen MI Ummul Qura, baik berupa dokumen tertulis seperti peraturan sekolah, jadwal pelajaran, buku panduan kurikulum, RPP, silabus, kalender akademik, serta dokumen yang berbentuk foto atau

\footnotetext{
${ }^{18}$ Wawancara dengan ustadzah Malisa, S.Pd, Wali kelas 1 di MI Ummul Qura.

${ }^{19}$ Wawancara dengan ustadzah Herlina, SE, Guru mata pelajaran matematika di MI Ummul Qura.
} 
video dan data lain-lainnya. Teknik pengumpulan data dalam penelitian ini adalah menggunakan teknik observasi, wawancara, studi dokumentasi. Ketiga teknik ini digunakan diharapkan dapat memperoleh data dan informasi yang diperlukan dan dapat saling menunjang dan saling melengkapi. Sementara sebagai instrumen pengumpul data adalah peneliti sendiri (human intsrument) untuk memandu peneliti dalam pengumpulan data dan klasifikasi data, maka sebelumnya peneliti telah mempersiapkan kisi-kisi pengumpulan data. Analisis data dimulai dengan menelaah seluruh data yang dikumpulkan dari berbagai sumber, yaitu dari hasil pengamatan, wawancara, studi dokumen. Dalam menganalisis, peneliti melakukan interpretasi terhadap data-data yang berupa katakata, sehingga diperoleh makna (meaning). Karena itu analisis dilakukan bersama-sama dengan proses pengumpulan data, serta setelah data terkumpul. Data yang dikumpulkan direduksi, yakni menggolongkan, mengarahkan, membuang yang tidak perlu, dan mengorganisasi data. Kemudian setelah data-data direduksi, peneliti melakukan penyajian data, yakni menemukan pola-pola hubungan yang bermakna serta memberikan kemungkinan adanya penarikan kesimpulan data tersebut. Yang terakhir peneliti, menyimpulkan data-data dengan membuat makna tentang peristiwa-peristiwa yang terjadi. 


\section{Hasil Penelitian}

Dari penelitian yang telah dilakukan oleh peneliti dengan judul "Peran Guru dalam Mengatasi Kesulitan Belajar Siswa pada Mata Pelajaran Matematika di MI Ummul Qura, maka disimpulkan sejumlah data yang dianggap relevan dengan judul tersebut:

1. Peran guru dalam mengatasi kesulitan belajar siswa pada mata pelajaran matematika

a. Guru sebagai demonstrator

Menurut Moh. Uzer Usman tentang peran guru sebagai demonstrator, guru harus senantiasa mengembangkan dan meningkatkan kemampuan atau ilmu yang dimilikinya, guru juga seorang pelajar yang berarti bahwa guru senantiasa belajar terus menerus, menguasai materi yang diajarkannya, dan menguasai serta mampu melaksanakan keterampilanketerampilan dalam mengajar. ${ }^{20}$

Berdasarkan penyajian data terdahulu bahwa hasil observasi dan wawancara dengan guru mata pelajaran matematika tentang peran sebagai demonstrator, beliau selalu meningkatkan kemampuan dan mengembangkan ilmu serta keterampilan yang dimilikinya dengan mengikuti berbagai macam pelatihan seperti KPI dan SGI yang mana di sana

${ }^{20}$ Moch. Uzer Usman, Menjadi Guru Profesional ..., h. 9. 
diajarkan bagaimana cara mengajar dan belajar tentang materi matematika sehingga guru cukup menguasai materi yang diajarkannya, mampu memperagakan apa yang diajarkannya dan memiliki keterampilan dalam mengajar.

Berdasarkan uraian di atas dapat disimpulkan bahwa dalam perannya sebagai demonstrator, guru mata pelajaran matematika kelas 5 di MI Ummul Qura sudah melaksanakan perannya sesuai dengan teori yang telah dipaparkan sebelumnya.

b. Guru sebagai pengelola kelas

Menurut Moh. Uzer Usman tentang peran guru sebagai pengelola kelas guru harus memelihara lingkungan fisik kelasnya agar senantiasa menyenangkan untuk belajar, mengarahkan atau membimbing proses-proses intelektual dan sosial di dalam kelasnya, menyediakan kesempatan bagi siswa untuk sedikit demi sedikit mengurangi kebergantungannya pada gurusehingga mereka mampu membimbing kegiatannya sendiri, mengembangkan kemampuan siswa dalam menggunakan alat-alat belajar, menyediakan kondisi-kondisi yang memungkinkan siswa bekerja serta belajar, dan sebagainya. ${ }^{21}$

\footnotetext{
${ }^{21}$ Moch. Uzer Usman, Menjadi Guru Profesional ..., h. 10.
} 
Berdasarkan penyajian data terdahulu dari hasil observasi dan wawancara dengan guru mata pelajaran matematika tentang perannya sebagai pengelola kelas, beliau selalu berusaha agar suasana pembelajaran di kelas menjadi menarik dan menyenangkan diantaranya dengan menyajikan materi pembelajaran matematika dalam bentuk nyanyian sehingga suasana kelas menjadi menyenangkan, guru juga mengadakan semacam game cepat dalam mengerjakan soal perkelompok, kelompok yang lebih cepat menyelesaikan soal atau latihan yang diberikan maka akan mendapatkan hadiah (reward).

Guru mengajar tidak hanya duduk di kursi saja, beliau berkeliling kelas dan mendekati tempat duduk siswa serta memberi pengajaran tersendiri bagi siswa yang tidak memahami atau merasa kesulitan dalam pelajaran. Ketika siswa mengerjakan tugas, jika siswa yang termasuk dalam kategori pandai telah menyelesaikan latihan atau tugasnya terlebih dahulu, maka beliau akan memerintahkan siswa tersebut untuk membantu mengajari temannya yang merasa kesulitan, hal ini untuk menghindari suasana kelas menjadi ribut dan agar anak yang telah selesai tidak mengganggu temannya. Selain itu, dalam proses pembelajaran beliau juga 
selalu menegur jika ada siswa yang siswa yang ribut, berbicara dan tidak memperhatikan.

Berdasarkan uraian di atas, peneliti menyimpulkan bahwa dalam perannya sebagai pengelola kelas, guru mata pelajaran matematika kelas 5 di MI Ummul Qura sudah melakukan perannya sesuai dengan teori yang telah dipaparkan sebelumnya.

c. Guru sebagai motivator

Menurut Sardiman tentang peran guru sebagai motivator,guru hendaknya mampu meningkatkan kegairahan dan pengembangan kegiatan belajar siswa, merangsang dan memberikan dorongan serta reinforcement untuk mendinamisasikan potensi siswa, menumbuhkan swadaya (aktivitas) dan daya cipta (kreativitas), sehingga dinamika di dalam poses belajar mengajar dapat terlaksana. ${ }^{22}$

Berdasarkan penyajian data terdahulu dari hasil wawancara dengan guru matematika tentang perannya sebagai motivator, beliau memang hanya terkadang dalam memotivasi siswa, tetapi bagi siswa yang mengalami kesulitan atau lambat dalam menerima pelajaran, beliau selalu menasehatinya dan secara tidak langsung beliau juga memotivasi dan membangkitkan semangat siswa dalam

${ }^{22}$ Sardiman, Interaksi\&Motivasi ..., h. 145. 
belajar dengan memberikan hadiah (reward) ketika siswa bisa menjawab soal atau latihan yang beliau berikan dalam pembelajaran menggunakan media.

Berdasarkan uraian dan teori yang telah dikemukakan, dapat disimpulkan bahwa guru mata pelajaran matematika kelas 5 di MI Ummul Qura sudah melakukan perannya sebagai motivator.

d. Guru sebagai mediator dan fasilitator

Menurut Moh. Uzer Usman tentang peran guru sebagai mediator, guru hendaknya memiliki pengetahuan dan pemahaman yang cukup mengenai media pendidikan, guru juga harus memiliki keterampilan memilih dan menggunakan serta mengusahakan media tersebut dengan baik. Untuk itu guru perlu mengikuti latihan-latihan praktik secara kontinu dan sistematis, baik melalui pre service maupun melalui inservice training. Dalam memilih dan menggunakan media pendidikan harus sesuai dengan tujuan, materi, metode, evaluasi dan kemampuan guru serta minat dan kemampuan siswanya.Sebagai mediator guru juga menjadi perantara dalam hubungan antarmanusia. Untuk itu guru harus memiliki keterampilan mempergunakan pengetahuan tentang bagaimana orang berinteraksi dan berkomunikasi. Sedangkan perannya sebagai fasilitator, guru hendaknya dapat 
mengusahakan sumber belajar yang berguna serta dapat menunjang dalam pencapaian tujuan dan proses belajar mengajar, baik yang berupa narasumber, buku teks, majalah, atau surat kabar. ${ }^{23}$

Berdasarkan penyajian data terdahulu dari hasil observasi dan wawancara dengan guru matematika tentang peran beliau sebagai mediator dan fasilitator, beliau sering menggunakan media dalam pembelajaran, berupa alat peraga dan sejenisnya. Guru tersebut juga melibatkan siswa dalam penggunaan media ketika proses pembelajaran berlangsung sehingga siswa menjadi aktif dalam pembelajaran. Guru memiliki pengetahuan yang cukup tentang media pendidikan karena beliau sering mengikuti berbagai pelatihan guru. Beliau juga selektif dan mempertimbangkan banyak hal dalam memilih media pembelajaran yang akan digunakan, diantaranya alokasi waktu, kemudahan siswa dalam memahami dan keefektifan pembelajaran. Sedangkan berdasarkan observasi peneliti, guru juga sudah menjalankan perannya sebagai fasilitator, hal ini dapat dilihat ketika proses pembelajaran berlangsung para siswa semuanya memiliki buku pelajaran, buku tulis dan alat-alat lainnya yang dapat menunjang proses belajarnya.

${ }^{23}$ Moch. Uzer Usman, Menjadi Guru Profesional ..., h. 11. 
Berdasarkan uraian dan teori yang telahdikemukakan, dapat disimpulkan bahwa guru mata pelajaran matematika kelas 5 di MI Ummul Qura sudah melakukan perannya sebagai mediator dan fasilitator.

e. Guru sebagai evaluator Menurut Mulyasa tentang peran guru sebagai
evaluator, guru harus menguasai kemampuan seperti
memahami teknik evaluasi, baik tes maupun nontes yang
meliputi jenis masing-masing teknik, karakteristik, prosedur pengembangan, serta cara menentukan baik atau tidaknya ditinjau dari berbagai segi, validitas, reliabilitas, daya beda, dan tingkat kesukaran soal. ${ }^{24}$ Selain itu, menurut Moh. Uzer Usman, dalam satu kali proses belajar mengajar, guru hendaknya menjadi seorang evaluator yang baik. Kegiatan ini dimaksudkan untuk mengetahui apakah tujuan yang telah dirumuskan sudah tercapai atau belum, dan apakah materi yang diajarkan sudah tepat. ${ }^{25}$

Berdasarkan penyajian data terdahulu dari hasil observasi dan wawancara dengan guru matematika tentang perannya sebagai evaluator, beliau sering mengadakan evaluasi setelah memberikan materi pelajaran yang baru

\footnotetext{
${ }^{24}$ Mulyasa, Menjadi Guru Profesional Menciptakan Pembelajaran Kreatif dan Menyenangkan. (Bandung:PT Remaja Rosdakarya, 2013).h. 61.

${ }^{25}$ Moch. Uzer Usman, Menjadi Guru Profesional ..., h. 12.
} 
kepada siswa, baik itu dalam bentuk mengerjakan latihan ketika proses pembelajaran berlangsung atau dalam bentuk pekerjaan rumah (PR) untuk mengetahui tingkat kepahaman siswa. Beliau selalu mengadakan remedial dan menambahkan nilai ujian dengan nilai harian siswa jika ada siswa yang nilai ujian semesternya tidak memenuhi KKM. Selain itu beliau juga mengikuti SGI (Sekolah Guru Indonesia) yang mana beliau diajarkan bagaimana melalukan evaluasi yang baik, cara membuat soal yang benar, bagaimana bentuk soal yang salah dan sebagainya sehingga beliau memiliki pengetahuan yang memadai dalam melakukan evaluasi.

Berdasarkan uraian di atas, peneliti menyimpulkan bahwa dalam perannya sebagai evaluator, guru mata pelajaran matematika kelas 5 di MI Ummul Qura sudah melakukan perannya sesuai dengan teori yang telah dipaparkan sebelumnya.

2. Faktor-faktor yang mempengaruhi kesulitan belajar siswa pada mata pelajaran matematika

a. Faktor internal

1) Minat

Menurut Ahmad Susanto, minat berarti kecenderungan dan kegairahan yang tinggi atau keinginan yang besar terhadap sesuatu. Seorang siswa akan 
memusatkan perhatiannya lebih banyak daripada siswa lainnya dalam pelajaran jika siswa itu memiliki minat yang besar terhadap pelajaran tersebut. Kemudian karena pemusatan perhatian yang intensif terhadap materi itulah yang memungkinkan siswa tadi untuk belajar lebih giat lagi, dan akhirnya mencapai prestasi yang diinginkan. ${ }^{26}$.

Berdasarkan penyajian data terdahulu dari hasil wawancara dengan siswa yang mengalami kesulitan belajar matematika diantaranya, Siti Armanita, Fadea Imani Putri, Mutia Imani Putri dan Sirajul Ilmi, mereka mengatakan kurang berminat terhadap pelajaran matematika. Kurangnya minat siswa terhadap mata pelajaran matematika sehingga mengakibatkan mereka kesulitan dalam pelajaran matematika tersebut. Berdasarkan uraian tersebut dapat disimpulkan bahwa minat merupakan salah satu faktor yang mempengaruhi kesulitan siswa pada mata pelajaran matematika kelas 5 di MI Ummul Qura.

2) Kecerdasan atau intelegensi siswa

Menurut Ahmad Susanto, cepat atau lambatnya penerimaan informasi serta terpecahkan atau tidaknya suatu permasalahan dipengaruhi oleh kemampuan intelegensi seseorang. Untuk menentukan apakah siswa itu mampu

${ }^{26}$ Ahmad Susanto, Teori Belajar \& Pembelajaran..., h. 17. 
mengikuti pelajaran yang diberikan dan untuk meramalkan keberhasilan siswa setelah mengikuti pelajaran yang diberikan, seorang pengajar dapat melihatnya melalui bagaimana kecerdasan siswa tersebut meskipun tidak akan terlepas dari faktor lainnya. ${ }^{27}$

Berdasarkan penyajian data terdahulu dari hasil wawancara dapat diketahui bahwa diantara siswa yang mengalami kesulitan pada mata pelajaran matematika, ada diantaranya siswa yang rendah kecerdasan dan kemampuannya. Hal ini dapat diketahui ketika ada orang tua siswa yang secara langsung memberitahu pada guru mata pelajaran matematika bahwa anak beliau tersebut memang kurang dalam pelajaran matematika. Selain itu, ketika peneliti melakukan observasi dengan mengikuti pembelajaran matematika di kelas 5 , terlihat anak tersebut memang termasuk lambat dalam menerima dan menangkap pelajaran. Kecerdasan atau intelegensi akan mempengaruhi cepat atau lambatnya penerimaan informasi maupun ilmu pengetahuan. Oleh karena itu, siswa yang kecerdasannya memang agak lambat akan mengakibatkan ia kesulitan dalam menerima pelajaran. Berdasarkan uraian tersebut dapat disimpulkan bahwa kecerdasan atau intelegensi siswa

${ }^{27}$ Ahmad Susanto, Teori Belajar \& Pembelajaran..., h. 15. 
merupakan salah satu faktor yang mempengaruhi kesulitan siswa pada mata pelajaran matematika kelas 5 di $\mathrm{MI}$ Ummul Qura.

3) Kemauan belajar

Menurut Ahmad Susanto, Kemauan belajar yang tinggi disertai dengan rasa tanggung jawab yang besar tentunya berpengaruh positif terhadap hasil belajar yang diraihnya. Karena untuk mencapai keberhasilan belajar salah satu faktor penentunya ialah adanya kemauan belajar. $^{28}$

Berdasarkan penyajian data terdahulu dari hasil wawancara dapat diketahui bahwa siswa mengalami kesulitan pada mata pelajaran matematika karena kurangnya kemauan untuk belajar dalam dirinya, sering menunda-nunda bahkan malas untuk belajar. Siswa yang tidak memiliki kemauan dan kesadaran bahwa belajar itu penting, maka cenderung di dalam dirinya akan timbul sifat malas untuk belajar. Berdasarkan uraian tersebut dapat disimpulkan bahwa kemauan belajar siswa merupakan salah satu faktor yang mempengaruhi kesulitan siswa pada mata pelajaran matematika kelas 5 di MI Ummul Qura.

${ }^{28}$ Ahmad Susanto, Teori Belajar \& Pembelajaran..., h. 17. 
4) Kondisi tubuh

Menurut Muhibbin Syah, diantara faktor yang menyebabkan timbulnya kesulitan belajar pada siswa ialah faktor intern siswa, yaitu keadaan yang timbul dari dalam diri siswa itu sendiri. Diantara faktor dari dalam diri siswa yang dapat mempengaruhi kesulitan belajar siswa yaitu kondisi tubuh seperti mengantuk, kelelahan dan sebagainya. $^{29}$

Berdasarkan penyajian data terdahulu dari hasil wawancara dan observasi peneliti, dapat dilihat dan diketahui bahwa diantara penyebab siswa mengalami kesulitan pada mata pelajaran matematika ialah karena dia mengantuk dan kelelahan ketika proses pembelajaran berlangsung sehingga siswa kurang memperhatikan penjelasan guru di depan. Siswa yang mengalami kondisi tubuh yang kurang baik seperti mengantuk dan kelelahan, maka respon atau penerimaan terhadap pelajaran menjadi terganggu sehingga dapat menimbulkan kesulitan dalam belajarnya. Berdasarkan uraian tersebut dapat disimpulkan bahwa kondisi tubuh siswa merupakan salah satu faktor yang mempengaruhi kesulitan siswa pada mata pelajaran matematika kelas 5 di MI Ummul Qura.

${ }^{29}$ Muhibbin Syah, Psikologi Belajar..., h. 184. 
b. Faktor eksternal

1) Lingkungan sosial atau teman bergaul

Menurut Abu Ahmadi dan Widodo Supriyono, pengaruh teman bergaul sangat besar dan lebih cepat masuk dalam jiwa anak. Apabila anak suka bergaul dengan mereka yang tidak sekolah, maka ia akan malas belajar, karena cara hidup anak yang bersekolah berbeda dengan anak yang tidak bersekolah. ${ }^{30}$

Berdasarkan penyajian data terdahulu dari hasil wawancara dapat diketahui bahwa diantara siswa yang mengalami kesulitan pada mata pelajaran matematika disebabkan karena terpengaruh lingkungan dan teman sebaya, ia lebih sering bermain bersama teman-teman sebayanya di sekitar rumah daripada belajar atau mengulang pelajaran dirumah. Tidak dapat dipungkiri bahwa pengaruh teman bergaul sangat besar dalam diri siswa, sehingga siswa yang lebih suka bergaul atau bermain dengan teman-temannya kemungkinan akan malas untuk belajar. Berdasarkan uraian tersebut dapat disimpulkan bahwa lingkungan sosial atau teman bergaul siswa merupakan salah satu faktor yang mempengaruhi kesulitan

\footnotetext{
${ }^{30}$ Abu Ahmadi dan Widodo Supriyono, Psikologi Belajar..., h.92-93.
} 
siswa pada mata pelajaran matematika kelas 5 di $\mathrm{MI}$ Ummul Qura.

2) Media massa

Menurut Abu Ahmadi dan Widodo Supriyono, media massa yang meliputi televisi, handphone, surat kabar, majalah, komik, dan sebagainya, akan menghambat belajar anak apabila ia terlalu banyak mempergunakan waktunya untuk hal-hal tesebut, sehingga melupakan akan tugas belajarnya. ${ }^{31}$

Berdasarkan penyajian data terdahulu dari hasil wawancara dapat diketahui bahwa siswa yang mengalami kesulitan pada mata pelajaran matematika disebabkan karena adanya pengaruh dari media massa, diantaranya handphone (HP), siswa lebih senang bermain handphone daripada belajar matematika dirumah. Siswa yang lebih sering bermain handphone dirumah kemungkinan akan melupakan tugasnya sebagai seorang pelajar yaitu untuk senantiasa belajar, baik itu di sekolah maupun di rumah. Berdasarkan uraian tersebut dapat disimpulkan bahwa media massa merupakan salah satu faktor yang mempengaruhi kesulitan siswa pada mata pelajaran matematika kelas 5 di MI Ummul Qura.

${ }^{31}$ Abu Ahmadi dan Widodo Supriyono, Psikologi Belajar..., h. 92. 
3) Suasana pengajaran

Menurut Ahmad Susanto, faktor lain yang mempengaruhi keberhasilan siswa dalam belajar adalah suasana pengajaran. Agar keberhasilan siswa dalam belajar dapat meningkat secara maksimal, maka suasana pengajaran yang sedang berlangsung harus tenang, adanya dialog yang kritis antara siswa dengan guru, dan menumbuhkan suasana yang aktif di antara siswa untuk memberikan nilai lebih pada proses pengajaran. ${ }^{32}$

Berdasarkan penyajian data terdahulu dari hasil wawancara dan observasi peneliti, dapat dilihat dan diketahui bahwa siswa merasa terganggu dan kesulitan menangkap pelajaran karena suasana pengajaran di kelas yang bisa dikatakan ribut, tidak tenang, ada siswa yang berbicara, berteriak, bahkan saling mengolok dan mengejek temannya ketika pelajaran berlangsung, sehingga hal ini mempengaruhi konsentrasi dan ketenangan siswa dalam menerima pelajaran. Siswa yang konsentrasinya terganggu karena suasana pengajaran yang kurang tenang mengakibatkan ia kesulitan dalam menangkap dan menerima pelajaran. Berdasarkan uraian tersebut dapat disimpulkan bahwa suasana pengajaran merupakan salah

\footnotetext{
${ }^{32}$ Ahmad Susanto, Teori Belajar \& Pembelajaran ..., h. 17-18.
} 
satu faktor yang mempengaruhi kesulitan siswa pada mata pelajaran matematika kelas 5 di MI Ummul Qura.

4) Lingkungan keluarga

Menurut Muhibbin Syah, lingkungan keluarga juga merupakan salah satu faktor yang mempengaruhi kesulitan belajar siswa contohnya seperti hubungan antara ayah dan ibu yang tidak harmonis dan kehidupan ekonomi keluarga yang rendah. ${ }^{33}$

Berdasarkan penyajian data terdahulu dari hasil wawancara dapat diketahui bahwa diantara siswa yang mengalami kesulitan belajar diantaranya ada siswa yang termasuk anak broken home, sehingga untuk belajar dirumah ia terkadang sulit untuk melaksanakan. Lingkungan keluarga yang harmonis antara ibu dan ayah juga dapat menunjang prestasi belajar siswa. Sebaliknya, hubungan keluarga antara ibu dan ayah yang tidak lagi harmonis dapat mempengaruhi belajar siswa. Berdasarkan uraian tersebut dapat disimpulkan bahwa lingkungan keluarga merupakan salah satu faktor yang mempengaruhi kesulitan siswa pada mata pelajaran matematika kelas 5 di MI Ummul Qura.

${ }^{33}$ Muhibbin Syah, Psikologi Belajar..., h. 185. 


\section{Simpulan}

Setelah diadakan penelitian lebih mendalamtentang peran guru dalam mengatasi kesulitan belajar siswa pada mata pelajaran matematika di MI Ummul Qura, maka dapat diambil kesimpulan bahwa:

1. Peran guru dalam mengatasi kesulitan belajar siswa pada mata pelajaran matematika kelas 5 di MI Ummul Qura sudah baik dalam pelaksanaanya, guru sudah melaksanakan perannya sebagai demonstrator, pengelola kelas, motivator, mediator, fasilitator dan evaluator sesuai dengan teori yang telah dikemukakan.

2. Faktor-faktor yang mempengaruhi kesulitan belajar siswa pada mata pelajaran matematika kelas 5 di MI Ummul Qura, disebabkan oleh beberapa faktor, diantaranya:

a. Faktor internal
1) Minat
2) Kecerdasan dan intelegensi siswa
3) Kemauan belajar
4) Kondisi tubuh

b. Faktor eksternal
1) Lingkungan dan teman sebaya
2) Media massa dan teknologi 
BADA'A: Jurnal Ilmiah Pendidikan Dasar

Vol. 2, No. 1, Juni 2020, Hal.35-64

E-ISSN 2714-7711

3) Suasana pengajaran

4) Lingkungan keluarga 


\section{DAFTAR PUSTAKA}

Abdurrahman, Mulyono. Anak Berkesulitan Belajar: Teori, Diagnosis, Dan Remediasinya. Jakarta: Rineka Cipta, 2012.

Afandi,Muhammad, Evi Chamalah, dan Oktarina Puspita Wardani. Model Dan Metode Pembelajaran Di Sekolah. Semarang: Unissula Press, 2013.

Ahmadi, Abu dan Widodo Supriyono.Psikologi Belajar. Jakarta: Rineka Cipta, 2013.

Arifin, Usman dan Ratni Purwasih. "Penerapan Pembelajaran Berbasis Alternative Solutions Worksheet Untuk Meningkatkan Kemampuan Berpikir Kreatif Matematik." Jurnal Pendidikan matematika FKIP Universitas Muhammadiyah Metro6, no. 2 (2017): h. 226.

Departemen Agama RI.Al-Qur'an dan Terjemahnya. Jawa Barat: CV Penerbit Diponegoro, 2015.

Kunandar. Guru Profesional: Implementasi Kurikulum Tingkat Satuan Pendidikan (KTSP) dan Sukses dalam Sertifikasi Guru. Jakarta: PT RajaGrafindo Persada, 2007.

Mulyasa. Menjadi Guru Profesional Menciptakan Pembelajaran Kreatif dan Menyenangkan. Bandung:PT Remaja Rosdakarya, 2013.

Nurfuadi.Profesionalisme Guru. Purwokerto: STAIN Press, 2012.

Sardiman. Interaksi\&Motivasi Belajar Mengajar. Jakarta: Rajawali Pers, 2009.

Susanti, Elsa dan Salmaini Safitri Syam. "Peran Guru dalam Meningkatkan Kemampuan Literasi Matematika Siswa Indonesia." Seminar Matematika Dan Pendidikan Matematika UNY, ISBN 978-602-73403-3-6 (2017): h. 273.

Susanto, Ahmad. Teori Belajar \& Pembelajaran di Sekolah Dasar. Jakarta: Prenadamedia Group, 2016.

Syah, Muhibbin. Psikologi Belajar Jakarta:PT Rajagrafindo Persada, 2007. 
BADA'A: Jurnal Ilmiah Pendidikan Dasar

Vol. 2, No. 1, Juni 2020, Hal.35-64

E-ISSN 2714-7711

Usman, Moch. Uzer. Menjadi Guru Profesional. Bandung: PT Remaja Rosdakarya, 2013. 